Biol. Stud. 2016: 10(2); 15-22 • DOI: https://doi.org/10.30970/sbi.1002.488

www.http://publications.Inu.edu.ua/journals/index.php/biology

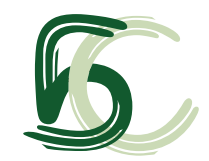

UDC: $616-006 /-08: 57.04$

\title{
THE EFFECT OF PERIOPERATIVE ANALGESIA WITH OMNOPON AND PARECOXIB ON THE ENDOCYTIC ACTIVITY OF MURINE PHAGOCYTES ON THE MODEL OF TUMOR SURGERY
}

\author{
R. I. Sydor ${ }^{1,2}$, N. M. Khranovska', O. V. Skachkova', L. M. Skivka ${ }^{2}$ \\ ${ }^{1}$ National Cancer Institute, Lomonosov St., 33/43, Kyiv 03022, Ukraine \\ ${ }^{2}$ Taras Shevchenko National University of Kyiv \\ 64, Volodymyrska St., Kyiv 01601, Ukraine \\ e-mail: creatogen@gmail.com
}

We used the model of surgical tumor removal to compare the effect of anesthesia with opioid analgesic omnopon and selective cyclooxygenase-2 inhibitor parecoxib on the endocytic activity of phagocytes of different localization sites. $50 \mathrm{C} 57 /$ black mice were transplanted with Lewis lung carcinoma in the hind paw pad. After 22 days, the tumor paw was amputated. Analgesics (omnopon $10 \mathrm{mg} / \mathrm{kg}$, parecoxib - $20 \mathrm{mg} / \mathrm{kg}$ ) were administered $30 \mathrm{~min}$ before the operation and once per day for 3 days after the surgery. Assessment of the endocytic activity of phagocytes was performed by FACS analysis before the surgery, at days 1 and 3 after the surgery. It was found that parecoxib analgesia maintained the endocytic activity of blood and spleen phagocytes in the postoperative period. At day 3 after the surgery in parecoxib-treated animals phagocytic activity of splenic granulocytes were 2.2 times higher compared to that in the group receiving opioid analgesia. Phagocytic indices of monocytes in parecoxib-treated mice were also 1.6 and 2.5 times higher for blood and spleen monocytes, respectively. Thus, parecoxib analgesia maintained the activity of blood and spleen phagocytes in mice after the surgical tumor removal at a much higher level as compared with the omnopon analgesia.

Keywords: phagocytic activity, perioperative analgesia, parecoxib, opioid drugs.

\section{INTRODUCTION}

Surgical excision is the mainstay of treatment for potentially curable solid tumours, but metastatic disease remains the most prevalent cause of cancer-related death in these patients. Recent studies demonstrated that surgical and traumatic injury profoundly affects both innate and adaptive immune responses [4]. The immune suppression following an excessive inflammatory response after surgery can create conditions for tumor immune-evasion, thus, promoting the metastatic process.

In addition, the prolonged inflammation promotes a spread of tumor cells [2]. Thus, minimization of postoperative inflammation could reduce the risk of relapse and meta-

ISSN 1996-4536 (print) • ISSN 2311-0783 (on-line) • Біологічні Студії / Studia Biologica • 2016 • Том 10/№2 • C. 15-22 
stasis. Phagocyte system is essential for both development and resolution of inflammatory response [7]. During the onset of inflammation, phagocytes polarize to pro-inflammatory phenotype with substantial production of reactive oxygen species and pro-inflammatory cytokines. These lead to the elimination of inflammatory triggers and switch to anti-inflammatory phenotype of phagocytes with a subsequent resolution of inflammation. Potent endocytic activity, which is among the features of this phenotype, serves for the clearance of neutrophils dying of netosis, and tissue debris which is the result of inflammatory cells destruction. A decrease in the endocytic activity of phagocytes may be the reason for chronization of inflammation, thus, promoting tumor progression [10].

Surgical stress factors that suppress immune cells functions, include tissue trauma, pain, and premedication pharmaceuticals, such as anaesthetic drugs and opioid analgesics. Despite opioids are often used for treatment of surgical and cancer pain, recent studies suggest that opioid administration have inhibitory effects on antibody production, natural killer cell activity, cytokine expression, and functional activity of phagocytes $[4,8]$. Consequently, there is a search of alternative analgesics which can at least partially substitute opioids for perioperative pain relief in tumor surgery in order to maintain immune function of cancer surgical patients on high level. In this respect, cyclooxygenase-2 (COX-2) inhibitors are of a particular interest as they were also reported to influence cancer incidence [3, 13].

In this study, we aimed to compare the effect of the perioperative analgesia with opioid drug omnopon and selective COX-2 inhibitor parecoxib on the endocytic activity of phagocytes using a murine model of surgical tumor excision.

\section{MATERIALS AND METHODS}

50 males of C57/black mice (18-22 g, 1.5 months old) were used. Animals were housed in an animal care facility of the National Cancer Institute, Ukraine. All procedures with animals were performed in accordance with the principles of humanity as it was written in "General principles of animal experimentation" approved by the National Congress on Bioethics (Kyiv, 2001-2007) and in accordance with Council directive of 24 November 1986 on the approximation of laws, regulations and administrative provisions of the Member States regarding the protection of animals used for experimental and other scientific purposes (86/609/EEC). The BioEthical Committee protocol No. 60 of the National Cancer Institute was approved in June 16, 2015. Lewis lung carcinoma (LLC) cell line was used as an experimental tumor model. LLC cells were kindly provided by the Bank of Cell Line of R. E. Kavetsky Institute of Experimental Pathology, Oncology and Radiobiology, NAS of Ukraine. LLC cells were transplanted subcutaneously into the right hind paw in the amount of $4 \times 10^{5}$ cells per mouse. After the tumor cell transplantation experimental animals were randomized by weight and assigned to 3 groups (15 animals per group): experimental group I (received for perioperational analgesia $10 \mathrm{mg} / \mathrm{kg}$ of opioid drug omnopon), experimental group II (received for perioperational analgesia $20 \mathrm{mg} / \mathrm{kg}$ of COX-2 inhibitor parecoxib) and control group (received equivalent volume of saline). 5 mice were leaved without tumor transplantation and used as an intact control.

Surgical removal of tumor was performed on $22^{\text {nd }}$ day after inoculation. Mice were anesthetized by ketamine ( $25 \mathrm{mg} / \mathrm{kg}$ intraperitoneally), tumor paw was ligated and amputated on the level of knee joint. Analgesic drugs (or saline in control group) were injected

ISSN 1996-4536 (print) • ISSN 2311-0783 (on-line) • Біологічні Студії / Studia Biologica • 2016 • Том 10/№2 • С. 15-22 
intraperitoneally 30 min before the tumor excision and once a day for 3 days after the surgery (4 injections in total). 5 mice per group were euthanized by cervical dislocation at 3 time-points: before the surgery, $1^{\text {st }}$ and $3^{\text {rd }}$ day after surgery. Blood and spleens were taken for the evaluation of monocytes and granulocytes phagocytic activity.

Phagocytic activity was assessed by FACS analysis. Briefly, $50 \mu$ of blood or splenocytes' suspensions $\left(2 \times 10^{6} \mathrm{cells} / \mathrm{ml}\right)$ were mixed with $40 \mu$ of FITC-labeled Staphylococcus aureus Cowan I $\left(1 \times 10^{7}\right.$ cells $\left./ \mathrm{ml}\right)$ and incubated at $37^{\circ} \mathrm{C}$ for $30 \mathrm{~min}$. Then $2 \mathrm{ml}$ of cold erythrocyte lysis solution containing EDTA was added for $10 \mathrm{~min}$ to stop the reaction, and then cells were washed twice with phosphate buffered saline. Results were assessed using FACSCalibur flow cytometer and CellQuest software (Becton Dickinson, USA). Granulocytes or monocytes were gated according to forward and side scatter. Phagocytosis percentage was measured as a percentage of fluorescence emitting cells ( $S$. aureus engulfed cells) in the respective gate, and phagocytic index was measured as a geometric mean fluorescence of these cells (which represents the mean number of bacterial cells engulfed by one phagocyte).

Statistical analysis was conducted in Statistica 10 software (StatSoft Inc., USA) using the one-way analysis of variance (ANOVA) and Wilcoxon test. Differences with type I error $<0.05$ were considered as statistically significant.

\section{RESULTS AND DISCUSSION}

Surgical trauma and pharmaceuticals used markedly perioperative reduce the activity of the immune cells, including phagocytes, such as neutrophils, monocytes and macrophages [5]. Phagocytes of peripheral blood and spleen play a key role in the resolution of postoperative inflammation, thus reducing the risk of relapse and metastases. Peripheral blood phagocytes eliminate apoptotic cells and residual tumor cells which can spread to circulation after the surgery. Circulating antigens are also filtered and eliminated in spleen by splenic phagocytes [1].

In the present study, we observed a decrease in phagocytosis percentage of granulocytes in peripheral blood at $1^{\text {st }}$ day after the surgical removal of transplanted tumor with its subsequent recovery at $3^{\text {rd }}$ day (Fig. 1). This can be explained by surgical trauma and blood loss with further reparative process. Analgesia with omnopon, however, notably depresses this postoperative recovery of phagocytosis. Thus, phagocytosis percentage of peripheral blood granulocytes in control and parecoxib treated mice to postoperative $3^{\text {rd }}$ day recover almost to preoperative levels, while in omnopon treated mice its continue to decrease and at day 3 was $20 \%$ lower compared to control group $(p<0.05)$. Postoperative decrease in the phagocytic activity of blood granulocytes was also more pronounced in the omnopon group (Fig. $1, A$ ) where at $1^{\text {st }}$ day after the surgery phagocytic index was 2.3 times lower compared to parecoxib group $(p<0.05)$. All these findings are consistent with data indicating that morphine can affect the myeloproliferation and inhibit functional activity of neutrophils (reactive oxygen species production, complement receptor synthesis and phagocytosis) [2].

Proportion of splenic granulocytes with phagocytic capacity decreased significantly after the surgery in control group and omnopon group while in parecoxib group it changed only slightly throughout the perioperative period (Fig. 1, B). In addition, phagocytic activity of these cells at $3^{\text {rd }}$ day post-surgery was 2.2 times higher in parecoxib treated animals compared to omnopon analgesia group $(p<0.05)$.

ISSN 1996-4536 (print) • ISSN 2311-0783 (on-line) • Біологічні Студії / Studia Biologica • 2016 • Том 10/№2 • C. 15-22 

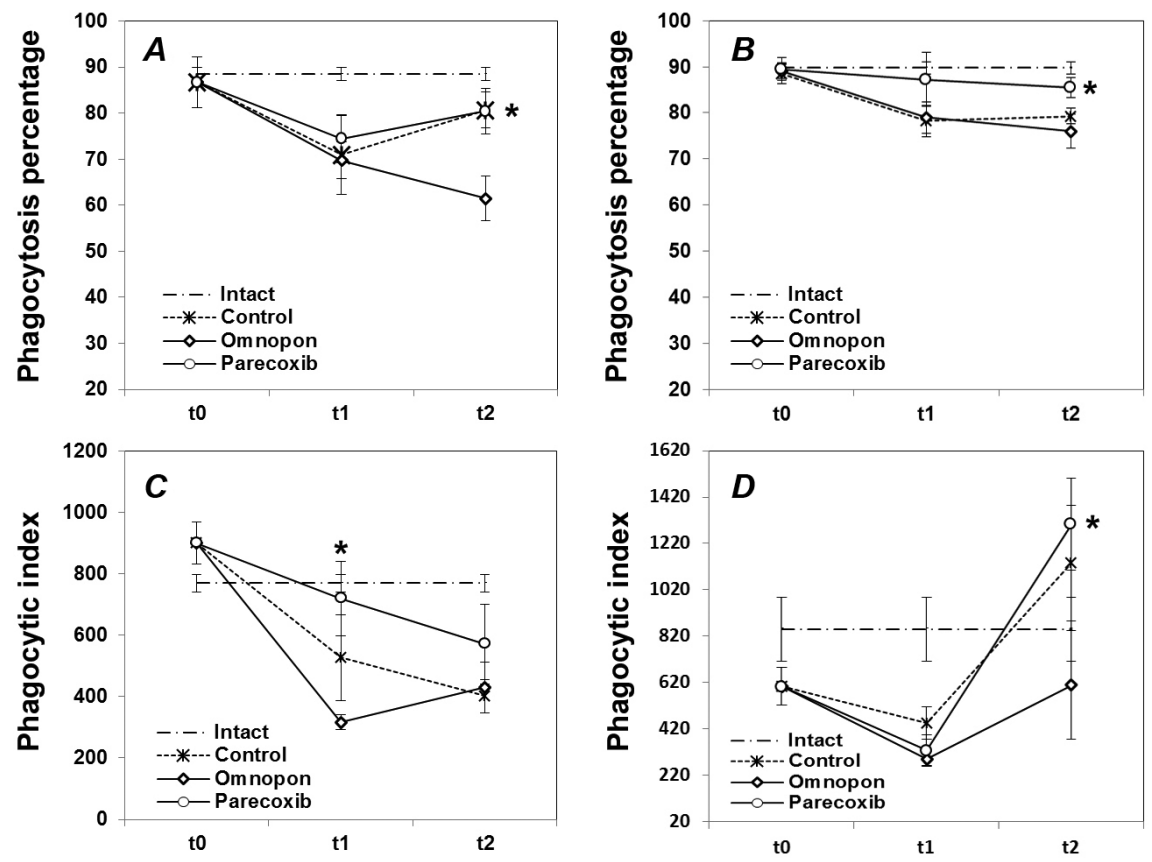

Fig. 1. Phagocytic activity of murine granulocytes before and after surgical removal of tumor: phagocytosis percentage of granulocytes of peripheral blood $(A)$ and spleen $(B)$; phagocytic index of granulocytes of peripheral blood $(C)$ and spleen $(D)$. t0 - before the surgery; t $1-1^{\text {st }}$ day after the surgery; t2 - $3^{\text {rd }}$ day after the surgery. The values presented are means \pm SEM $(n=5) ;{ }^{*}-p<0.05$ compared to omnopon-treated group

Рис. 1. Показники фагоцитарної активності гранулоцитів мишей до та після видалення пухлини: фагоцитарне число гранулоцитів крові $(A)$ та селезінки $(B)$; фагоцитарний індекс гранулоцитів крові $(C)$ та селезінки $(D)$. t0 - до операції; t1 - на 1 добу після операції; t2 - на 3 добу після операції. Значення представлені як середнє \pm похибка середнього ( $n=5)$; * $-p<0,05$ порівняно зі значеннями у групі, що отримувала омнопон

Mononuclear phagocytes were also affected by surgical stress (Fig. 2). Relative quantities of phagocytically active monocytes in peripheral blood were markedly reduced at day 1 after the operation compared to preoperative values in all studied groups (Fig. 2, A), which also could be a consequence of blood loss and migration to inflammation sites. At $3^{\text {rd }}$ day after the surgery phagocytosis percentage of circulating monocytes have increased compared to $1^{\text {st }}$ day levels, however, in omnopon treated mice this recovery reaches only $(47.3 \pm 4,7) \%$ as compared to $(59 \pm 3.8) \%$ in control group and $(61 \pm 4.9) \%$ in parecoxib group $(p<0.05)$. At the same time, the amount of splenic mononuclear phagocytes during postoperative period was higher in parecocxib treated mice (Fig. 2, $B$ ) (at $3^{\text {rd }}$ day post-surgery these values were $(61.0 \pm 3.1) \%$ in parecoxib group compared to $(52.5 \pm 3.2) \%$ and $(45.5 \pm 2,9) \%)$ in control and omnopon groups, respectively, $p<0.05)$.

Postoperative values of phagocytic indices of both peripheral blood and splenic monocytes were also higher in mice receiving parecoxib analgesia compared to omnopon and saline treated animals. Phagocytic activity in parecoxib group at $3^{\text {rd }}$ day after the surgery was 1.6 times higher for blood monocytes, and 2.5 times higher for splenic monocytes as compared to omnopon group $(p<0.05)$. 

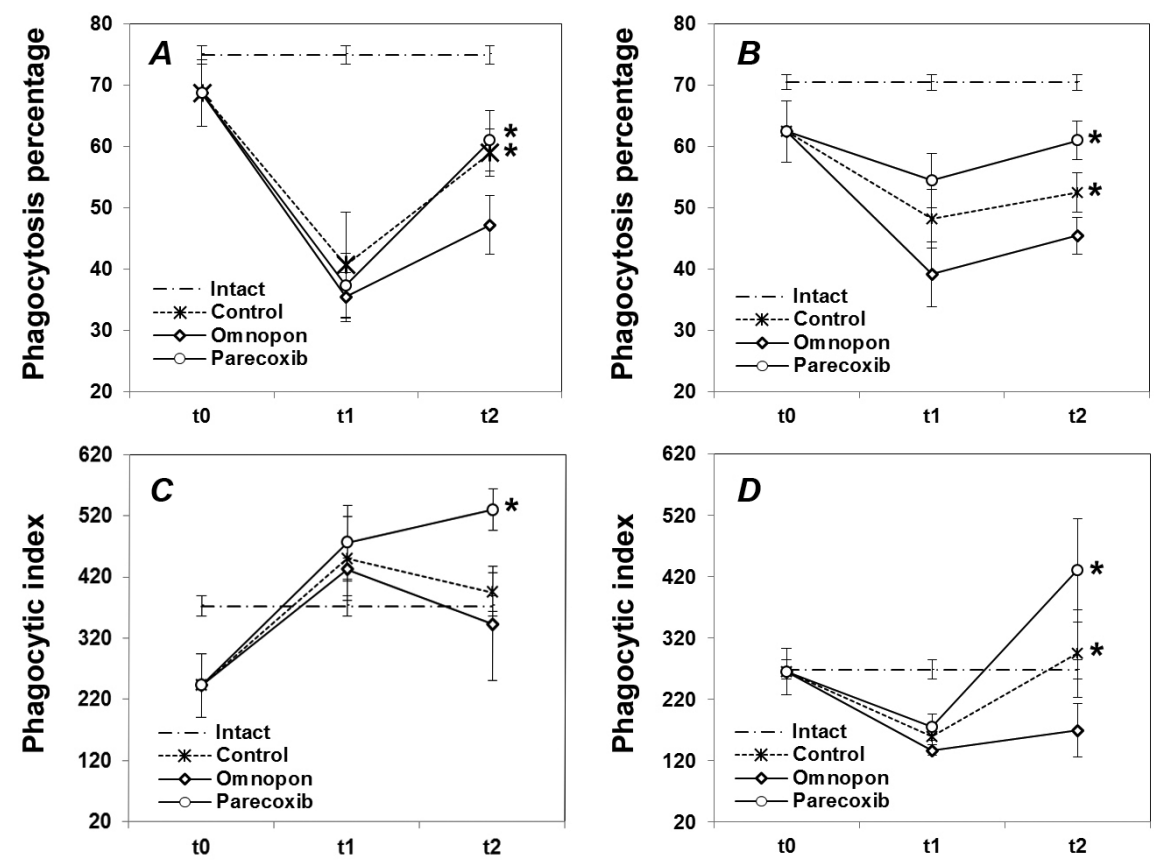

Fig. 2. Phagocytic activity of murine monocytes before and after surgical removal of tumor: phagocytosis percentage of monocytes of peripheral blood $(A)$ and spleen $(B)$; phagocytic index of monocytes of peripheral blood $(C)$ and spleen $(D)$. t0 - before the surgery; $\mathrm{t} 1-1^{\text {st }}$ day after the surgery; $\mathrm{t} 2-3^{\text {rd }}$ day after the surgery. Values presented are means $\pm \operatorname{SEM}(n=5) ;{ }^{*}-p<0.05$ compared to omnopontreated group

Рис. 2. Показники фагоцитарної активності моноцитів мишей до та після видалення пухлини: фагоцитарне число моноцитів крові $(A)$ та селезінки $(B)$; фагоцитарний індекс моноцитів крові $(C)$ та селезінки $(D)$. t0 - до операції; t1 - на 1 добу після операції; t2 - на 3 добу після операції. Значення представлені як середнє \pm похибка середнього ( $=5)$; * $-p<0,05$ порівняно зі значеннями у групі, що отримувала омнопон

Maintenance of high phagocytic activity of neutrophils and monocytes is crucial for the resolution of inflammation in postoperative period. Malfunction of mechanisms regulating inflammation resolution leads to chronization of inflammatory process accompanied by decline of adaptive immune response and promotion of metastasizing $[11,12]$.

Perioperative analgesia with COX-2 inhibitor parecoxib resulted in preservation of phagocytic function of granulocytes and monocytes on higher levels compared to control animals. COX-2 is one of the key enzymes in the development of inflammation and its overexpression may lead to prolonged inflammatory process [6]. COX-2 product prostaglandin E2 (PGE2) exerts an inhibitory effect on the endocytic activity of phagocytes [12], and is suggested to link chronic inflammation with tumor growth promotion $[6,12]$. Inhibition of COX-2 by parecoxib during perioperative period may neutralize negative influence of PGE2 on the phagocytic function.

On contrary, analgesia with opioid drug omnopon led to more potent decrease in the postoperative endocytic activity and quantity of phagocytes in comparison with control and parecoxib treated animals. These results correspond to literature data confirming the negative effect of opiates on the phagocytic activity of monocytes and neutrophils [9, 4].

ISSN 1996-4536 (print) • ISSN 2311-0783 (on-line) • Біологічні Студії / Studia Biologica • 2016 • Том 10/№2 • C. 15-22 
To summarize, obtained results put forward the COX-2 inhibitor parecoxib as a promising alternative to the opioid drugs in the perioperative analgesia. Further studies may reveal the benefit of parecoxib in the reduction of metastases and the postoperative complications in surgical cancer patients.

1. Bronte V., Pittet M.J. The spleen in local and systemic regulation of immunity. Immunity, 2013; 39(5): 806-18.

2. George B.S., Richard M.K., Kirk J.M. et. al. Endogenous Morphine/Nitric Oxide-Coupled Regulation of Cellular Physiology and Gene Expression: Implications for Cancer Biology. Semin. Cancer. Biol, 2008; 8(3): 199-210.

3. Harris R.E. Cyclooxygenase-2 blockade in the chemoprevention of cancers of the colon, breast, prostate, and lung. Inflammopharmacology, 2009; 17: 55-67.

4. Kaye A., Patel N., Bueno F. et al. Effect of Opiates, Anesthetic Techniques, and Other Perioperative Factors on Surgical Cancer Patients. The Ochsner Journal, 2014; 14(8): 216-228.

5. Kimura F., Shimizu H., Yoshidome H. Immunosuppression following surgical and traumatic injury. Surg. Today, 2010; 40(9): 793-808.

6. Kundu J.K., Surh Y.J. Inflammation: gearing the journey to cancer. Mutat. Res, 2008; 659(1-2): 15-30.

7. Maskrey B.H., Megson I.L., Whitfield P.D. et. al. Mechanisms of Resolution of Inflammation a Focus on Cardiovascular Disease. Arterioscler. Thromb. Vasc. Biol, 2011; 31: 1001-1006.

8. Meserve J.M., Kaye A.D., Prabhakar A. et. al. The Role of Analgesics in Cancer Propagation. Best. Pract. Res. Clin. Anaesthesiol, 2014; 28(2): 139-51.

9. Shirzad H., Shahrani M., Rafieian-Kopaei M. Comparison of morphine and tramadol effects on phagocytic activity of mice peritoneal phagocytes in vivo. Int. Immunopharmacol, 2009; 9(7-8): 968-70.

10. Soehnlein O., Lindbom L. Phagocyte partnership during the onset and resolution of inflammation. Nat. Rev. Immunol, 2010; 10(6): 427-39.

11. Tanja $C$. The fundamental role of mechanical properties in the progression of cancer disease and inflammation. Reports on Progress in Physics, 2014; 77(7): 121-126.

12. Wu Y., Zhou B.P. Inflammation: a driving force speeds cancer metastasis. Cell Cycle, 2009; 8(20): 3267-3273.

13. Yiannakopoulou E. Targeting epigenetic mechanisms and microRNAs by aspirin and other non-steroidal anti-inflammatory agents - implications for cancer treatment and chemoprevention. Cell Oncol. (Dordr), 2014; 37(3):167-78.

ISSN 1996-4536 (print) • ISSN 2311-0783 (on-line) • Біологічні Студії / Studia Biologica • 2016 • Том 10/№2 • С. 15-22 


\title{
ВПЛИВ ПЕРІОПЕРАЦІЙНОГО ЗНЕБОЛЕННЯ ОМНОПОНОМ I ПАРЕКОКСИБОМ НА ЕНДОЦИТАРНУ АКТИВНІСТЬ ФАГОЦИТІВ МИШЕЙ НА МОДЕЛІ ХІРУРГІЧНОГО ВИДАЛЕННЯ ПУХЛИНИ
}

\author{
P. І. Сидор ${ }^{1,2}$, Н. М. Храновська ${ }^{1}$, О. В. Скачкова ${ }^{1}$, Л. М. Сківка \\ ${ }^{1}$ Національний інститут раку \\ вул. Ломоносова, 33/43, Київ 03022, Україна \\ ${ }^{2}$ Київський національний університет імені Тараса Шевченка \\ вул. Володимирська, 64, Київ 01601, Україна \\ e-mail: creatogen@gmail.com
}

Метою цього дослідження було порівняти вплив знеболення опіоїдним анальгетиком омнопоном і неселективним інгібітором ЦОГ-2 парекоксибом на ендоцитарну активність фрагоцитів різної локалізації на моделі хірургічного видалення пухлини. У дослідженні було використано 50 мишей лінії C57/black, яким перещеплювали карциному легені Льюїс у подушечку задньої лапи. На 22 добу лапу з пухлиною ампутували. Анальгетики (омнопон у дозі 10 мг/кг, парекоксиб 20 мг/кг) вводили за 30 хв до операції та 1 раз на добу впродовж 3 днів після операції. Оцінку ендоцитарної активності фрагоцитів проводили методом протокової цитометрії до, на 1 та 3 добу після операції. Було встановлено, що застосування парекоксибу сприяє підтриманню ендоцитарної активності фагоцитів крові та селезінки у післяопераційному періоді. На 3 добу після операції у групі тварин, що отримували для знеболення парекоксиб, фрагоцитарна активність гранулоцитів селезінки перевищувала у 2,2 разу відповідні значення у групі опіоїдної аналгезії. Фагоцитарні індекси моноцитів при знеболенні парекоксибом також були вищими у 1,6 та 2,5 разу для моноцитів крові та селезінки відповідно. Отже, при аналгезії парекоксибом активність фрагоцитів крові та селезінки мишей після операції зберігається на значно вищому рівні порівняно із застосуванням омнопону.

Ключові слова: фрагоцитарна активність, периопераційна аналгезія, парекоксиб, опіоїдні препарати.

\section{ВЛИЯНИЕ ПЕРИОПЕРАЦИОННОЙ АНАЛГЕЗИИ ОМНОПОНОМ И ПАРЕКОКСИБОМ НА ЭНДОЦИТАРНУЮ АКТИВНОСТЬ МИШИНЫХ ФАГОЦИТОВ НА МОДЕЛИ ХИРУРГИЧЕСКОГО УДАЛЕНИЯ ОПУХОЛИ}

\author{
Р. И. Сидор ${ }^{1,2}$, Н. Н. Храновская ${ }^{1}$, О. В. Скачкова ${ }^{1}$, Л. М. Скивка \\ ${ }^{1}$ Национальный институт рака \\ ул. Ломоносова, 33/43, Киев 03022, Украина \\ ${ }^{2}$ Киевский национальный университет имени Тараса Шевченко \\ ул. Владимирская, 64, Киев 01601, Украина \\ e-mail: creatogen@gmail.com
}

Целью данного исследования было сравнить влияние обезболивания с применением опиоидного анальгетика омнопона и неселективного ингибитора ЦОГ-2 парекоксиба на эндоцитарную активность фагоцитов различной локализации на модели хирургического удаления опухоли. Было использовано 50 мышей линии

ISSN 1996-4536 (print) • ISSN 2311-0783 (on-line) • Біологічні Студії / Studia Biologica • 2016 • Том 10/№2 • C. 15-22 
C57/black, которым перевивали карциному легких Льюис в подушечку задней лапы. На 22 сутки лапу с опухолью ампутировали. Анальгетики (омнопон в дозе 10 мг/кг, парекоксиб - 20 мг/кг) вводили за 30 мин до операции и 1 раз в сутки в течение 3 дней после операции. Оценку эндоцитарной активности фагоцитов проводили методом проточной цитометрии за сутки до, на 1 и 3 сутки после операции. Было установлено, что применение парекоксиба способствует поддержанию эндоцитарной активности фагоцитов крови и селезенки в послеоперационном периоде. На 3 сутки после операции в группе животных, получавших для обезболивания парекоксиб, фрагоцитарная активность гранулоцитов селезенки была в 2,2 раза выше по сравнению с группой, получавшей опиоидную аналгезию. Фагоцитарные индексы моноцитов при обезболивании парекоксибом также были выше в 1,6 и 2,5 раза выше для моноцитов крови и селезенки соответственно. Таким образом, при аналгезии парекоксиба активность фагоцитов крови и селезенки мышей после операции сохраняется на более высоком уровне по сравнению с применением омнопона.

Ключевые слова: фрагоцитарная активность, периоперационная аналгезия, парекоксиб, опиоидные препараты.

Одержано: 01.07.2016

ISSN 1996-4536 (print) • ISSN 2311-0783 (on-line) • Біологічні Студії / Studia Biologica • 2016 • Том 10/№2 • C. 15-22 